\title{
The social setting of Jesus' exaltation in Luke-Acts (Lk 22:69 and Ac 7:56)
}

\author{
Jean-Claude Loba-Mkole ${ }^{1}$ \\ United Bible Societies (Nairobi) \\ Research Associate: Department of New Testament Studies \\ University of Pretoria
}

\begin{abstract}
This article presents a model for "intercultural exegesis" and applies this model to Luke 22:69 and Acts 7:56. In this process, the term "Son of Man" is approached from two perspectives: that of a biblical culture in the first century Graeco-Roman world, and that of a current Christian culture in Africa. The study concludes that the "Son of Man" concept in the selected texts not only includes a reference to the eschatological saviour, judge and defender, but also creates a sense of Jesus' solidarity with his fellow human beings. Such an understanding would certainly have led to Jesus' exaltation by his followers, who lived under conditions of social turmoil in the Graeco-Roman world of the first century, and would lead to such an exaltation by those who experience similar circumstances in Africa today.
\end{abstract}

\section{INTRODUCTION}

In Luke 22:69 Jesus is portrayed as the "Son of Man" "sitting" at the right hand of God, while in Acts 7:56 he is "standing". It has been argued that this shift in the Son of Man's position in the Lukan corpus might have theological and literary meanings. The sitting position could imply the exaltation of Jesus, whereas the standing position may convey a variety of polysemous meanings, ranging from an attitude of welcome or salvation-vindication to judgment

\footnotetext{
${ }^{1}$ This article was presented at the Annual Congress of the New Testament Society of South Africa at the University of South Africa in Pretoria, 14-16 April 2004. It was dedicated to Prof Adelbert Denaux (Katholieke Unversiteit van Leuven) on the occasion of his sixty-fifth birthday, celebrated in September 2004. Dr Loba-Mkole, translation consultant for the United Bible Societies (Nairobi, Kenia), is an International Advisor of the Editorial Board of HTS Theological Studies. He participates as a Research Associate in the project "Biblical Theology and Hermeneutics", directed by Prof Dr Andries G van Aarde, Faculty of Theology, University of Pretoria.
} 
(Focant 1999: 575). ${ }^{2}$ Another view considers the phrase "Son of Man" sitting or standing at the right hand of God" as referring to the "heavenly enthronement of Jesus", in the sense that, after his resurrection, he was confessed as the one "sharing in the lordship of God" (Denaux 2002a:128, 140, 142; 2002b:55; 2003:222).

One of the key issues under consideration is the interpretation of the phrase "Son of Man". ${ }^{3}$ This study assumes a New Testament Christology that regards Jesus as the Son of God (divine) and as the Son of Man (human). ${ }^{4}$ The study attempts to show how the motif of Jesus' exaltation could not only fit into the social setting of the Graeco-Roman world (Malina 1993:31, 33, 37, $54 ; 2001: 147,153-154)$, but also be relevant to an African social context. This argument uses the method of intercultural exegesis, as described in the first part of the article. The second part of the article applies this method to Luke 22:29 and Acts 7:56. In this application, the reading strategies propounded by West (1993, 1995, 1999, 2000a, 2000b; West \& Dube 1996) is used to some extent. These strategies include "reading in front of the text" (an exploration of the relevance of the text for the African context), "reading in the text" (literary analysis) and "reading behind the text" (a historical-critical approach).

One of the key conclusions of this study is that the polysemous meaning of the phrase "Son of Man" in Luke 22:69 and Acts 7:56 might include the sense of Jesus' solidarity with human beings, which has prompted his exaltation, especially in the context of social unrest both in the first century Graeco-Roman world and in the present African context.

\section{INTERCULTURAL EXEGESIS}

\subsection{Definition}

Biblical intercultural exegesis involves a constructive dialogue between an original biblical culture and the culture of a receptive audience. In such a reading, culture is regarded as an all-embracing reality (Penoukou 1991:45) or a system of symbols relating and embracing people, things, and events. It

\footnotetext{
${ }^{2}$ In Focant's view, which is based on the accounts of Acts, Stephen is the object of the vindication by the Son of Man, whereas the passion narratives in the Synoptic Gospels (including Lk 22:69) generally express the vindication of the Son of Man by God. "He [Jesus] may then have been giving expression to his conviction that he, like others before him, was destined to suffer rejection, hostility and violence because of his commitment to God, but that he would be subsequently vindicated in the heavenly court" (Tuckett 2001:394).

${ }^{3}$ Generally speaking, in some New Testament scholarship circles, the phrase is considered to be a riddle (Gerleman 1983:1; Cothenet 1984:697; Luz 1992:3; Goulder 2002:18).

${ }^{4}$ See Loba-Mkole (1996:118; 2000a:562-563; 2000b:1137-1138; 2003:854-855). Wink (2002:xi; cf 259-260) holds that "'The son of the man' is the expression Jesus almost exclusively used to describe himself .... The implication seems that Jesus intentionally avoided honorific titles, and preferred to be known simply as 'the man', or 'the human being'."
} 
takes what is available in the physical and human environment, and fills it with socially shared meaning and feeling (Malina 1993:12-13). In other words, it reflects the totality of human experience in a given time and space (Kabasele 2003:22).

The phrase "original biblical culture" refers to the entire context in which the biblical author, his message and his first audiences were embedded. On the other hand, the culture of the "receptive audiences" of biblical messages pertains to the total environment of the people not "directly" addressed by the Bible. They might be alluded to as "Nations" in the Old Testament or as "Gentiles" in the New Testament, but without an explicit reference. More information about such people appears in non-biblical materials depicting the life styles of the past, present, and even the future. These materials include theological and historical writings, as found in religious documents like the Talmud, the Qumran scrolls, the Apostolic Creeds, the writings of the Church fathers, canon laws, and ethical codes; or in various theological teachings, biblical interpretations, pastoral endeavours and liturgical practices, and in archaeological evidence. These materials also constitute another set of cultures to be taken into consideration in the process of intercultural exegesis.

A constructive dialogue implies give-and-take, an exchange. It is a dialogue for conversion from both an original biblical culture and a target culture in the present time. In other words, it is a dialogue that leads to a mutual understanding, respect, transformation and enrichment beyond categories such as "true" or "false", "right" or "wrong", "bad" or "good", "spiritual" or "secular", "superior" or "inferior". No culture is absolutely true or superior to others. Similarly, no religion is better than others, given that none can guarantee eternal salvation as many claim. A religion does not save: it is God who saves, ${ }^{5}$ even though God may use individual and/or communal religious environments.

A constructive dialogue between a biblical original culture and an African receptive culture cannot be a "juxtaposition" of two or several religious worlds. This kind of dialogue remains superficial. It cannot be a "concordist assimilation" of some aspects of the original culture by the receptive one. Such a surface dialogue might just serve a number of selected interests of the receptive culture. It cannot be a "resignation-conversion" in which a receptive

\footnotetext{
${ }^{5}$ See Goldingay and Wright (1993:42-43; cf Denaux 2003:205): "There is salvation in no religion because religions don't save. Not even Israel's religion saved them." With regard to the notion of eternal salvation in a theistic religion (for example, eternal life for the Christians) and atheistic religion (for example, nirvana for the Buddhists), Küng et al (2001:328) conclude: "Because where God is not only 'in everything', but 'everything to everything' (1 Cor 15:28), then it will be manifest that human beings, who are never everything, still have a share in that everything that God is for Christians."
} 
culture attempts to deny itself for the sake of another culture. Juxtaposition, concordist assimilation and resignation-conversion are all types of dialogue that refuse the conversion of mentalities and practices prevailing in both the original and the receptive cultures (Thiamalenga 1977:183-184). The reason of this failure might be a lack of deep understanding and mutual respect.

Biblical intercultural exegesis in Africa seeks to develop a platform that can guarantee as considerate an understanding as possible and necessary, but not any obligatory conversion for either the biblical original culture or the African culture. ${ }^{6}$ A practical model such as that described below can enhance our comprehension of intercultural exegesis.

\subsection{A model of intercultural exegesis}

The term "model" is used here in the broad and general sense of an example, and it is hoped that this model will emerge as a "heuristic tool" (see Craffert 1992:217-239; 2001:21-46) that can be recommended for exegesis. Although many heuristic tools overlap in terms of how they develop theories and practices, it is also true that every model is unique in terms of its own strengths and limitations. However, what matters with regard to a heuristic tool is its usefulness (Esler 1994:23) or its "goodness of fit" (Carney 1975:11). However, if the assessment of the model's appropriateness becomes a goal in itself, this might complicate the interpretive process (Craffert 2001:46).

A recent book which consciously provides a model of intercultural hermeneutics or exegesis in Africa is that by Manus (2003), who considers intercultural hermeneutics "a necessary development in African New Testament scholarship". ${ }^{7}$ He defines it as "a methodology in biblical criticism

\footnotetext{
${ }^{6}$ See Bediako (2001:6): "If the gospel and culture engagement is about the process of coming together, the meeting of life with life, then it should be evident that the process of gospel and culture engagement as a process of conversion is rarely completed in one generation." Okure (2001:49) comments: "Better still inculturation gives the cultural analysis of the texts a living dimension; it allows God's life-giving word to affirm the good in all cultures and to challenge the sinful in them whether these be African cultures, the culture of the Church or ancient cultures embedded in the biblical text. The canon or yardstick of this task is God's gospel (Rm 1:1." Van Aarde (1994:577) speaks of a "dual engagement" in the sense of adapting the dispositions, methodologies and teleologies in theological inquiry from both a traditional theological and contextual theological perspective. For him, a dual engagement is a responsible way of doing relevant theology in a postmodern world.

${ }^{7}$ As far as the biblical interpretation is concerned, the boundaries of meaning between the terms "hermeneutics" and "exegesis" are fuzzy. This distinction is rightly qualified as "dubious" by West and Dube (1996:7). For Manus (2003:31), "hermeneutics is not essentially different from exegesis; and quite often the two are used synonymously in the academy." I nevertheless prefer to use the term "exegesis" in line with biblical scholarship to which this term is most commonly attributed (see Loba-Mkole 2004d). In addition, the qualifiers "inculturation" and "intercultural" can also be used synonymously, except that the latter
} 
which is applicable to biblical texts in order to facilitate interpretation and the appropriation of the meaning of God's self-disclosure in creation into another culture" (Manus 2003:34). Furthermore, Manus agrees with Ukpong (2001b), when he sees intercultural hermeneutics as an "academic reading of the Bible that is informed by the perspectives and concerns of ordinary readers and ordinary readings" (Manus 2003:139). One has the impression that Manus and Ukpong both use ordinary readers as informants in order to fulfil their academic agenda, but not as persons who have an equal epistemological privilege in building up a new culture of socio-spiritual upliftment, of which academic achievement is just one part among many others. ${ }^{8}$

What West says about the contextual Bible study can equally apply to a more considerate purpose of the inculturation hermeneutics. It implies a process that can provide a safe (and sacred) space for owning and articulating working theologies, both by academic and ordinary readers, for the sake of their survival, liberation, and life-theologies, which in turn form the foundations of social transformation. ${ }^{9}$ It is important to underscore that inculturation and liberation approaches in Africa operate in a dialectical

emphasizes mutual understanding and mutual conversion from different cultures engaged in the dialogical process. This process will then lead to a new original culture or a new creation (Rev 21:1). Furthermore, intercultural exegesis is to be seen as a deployment of an inculturation paradigm in the framework of African theology and biblical scholarship, rather than a quite new paradigm, in the sense in which Thomas Kuhn (1970) used it. West (2000a:35) argues: "The most persuasive paradigms within which African biblical scholarship functions are the inculturation and liberation paradigms" (see also Bediako 2000:7). Mugambi (2003:28-30) also speaks of reconstruction as a paradigm (see also Kä Mana 1993; 2000; Villa-Vicencio 1992; 1999). To paraphrase Joubert (2001:47), my aim is not to invent any new theory that might deserve the Kuhnian concept of "paradigm", but rather to articulate a possible feature of the ongoing African theology and its biblical component. Nonetheless, African theology and biblical scholarship have both been characterised as operating under the paradigms mentioned above. Draper (2003: xi) uses the term "enculturation" for what others have called "inculturation".

\footnotetext{
${ }^{8}$ Although Manus (2003:43) recognizes that intercultural hermeneutics "is mainly an interactive reading between the trained reader and the ordinary readers", he seems to be more convinced that "the intercultural hermeneutics has to be employed by the academically trained readers" (Manus 2003:36). A similar view has been expressed by Ukpong 2001a:191): "Inculturation hermeneutics is an intercultural hermeneutic methodology for academic reading of the Bible that is informed by the perspectives and concerns of ordinary readers and ordinary readings."

${ }^{9}$ See West (1999:143-144; cf 2000b:608): "Contextual Bible study is not a method, either in the sense of a set procedure in which certain steps are followed, or in the sense of a particular mode of reading being used. Contextual Bible study is more of consciousness, a set of commitments, and an orientation." As a matter of illustration, having studied Luke 4:16-22, a South African contextual Bible study group ended up with a poster in which they compiled the most important things that they had learnt, and the poster was put up on the wall of the group's office (West 1999:153). This case exemplifies how an "intercultural exegesis" was done and published by ordinary readers without their being used "only" as simple informants for academics.
} 
relationship, as the problems both of them address are interconnected and inseparable. $^{10}$

Most interestingly, Manus (2003) uses inculturation, liberation and reconstruction approaches as variants of intercultural hermeneutics. So, for example, Manus applies an inculturation approach to Paul's speech at the Areopagus, by analysing the text and the context of the speech on one the hand, and exposing an Igbo version (the Igbo are a Nigerian tribe) of that speech on the other hand. He employs a liberation approach to examine the issue of the Scriptures and women, comparing Yoruba sacred narratives (the Yoruba are another Nigerian tribe) and Pauline texts. Finally, he proceeds to a reconstructive re-reading of the cleansing of the temple (Mk 11:15-19), providing an analysis of the text and the socio-historical context of the story before interpreting it through the paradigm of "Jesus the Reconstructor". ${ }^{11}$ The model Manus uses closely follows the procedure proposed by Ukpong (2001b:2). It consists of carefully (methodically) reading a given biblical text; analysing a contemporary African context; pointing out the relationship between the biblical text and the African context; and using the insights from the African contemporary context to ask questions and provide answers (Manus 2003:40-41).

This procedure is also supported by Matand (1998) and Ndayango (2001, 2003). They respectfully speak of the "herméneutique de l'inculturation" and "interkulturelle Exegese" or "exégèse interculturelle" (see Matand

\footnotetext{
${ }^{10}$ See Ukpong (2003:119). A contrary view is expressed by Mugambi (2003:72-73): "In Africa, it seems that the project of inculturation pushes for inculturation without liberation. The emphasis on culture in the literature on inculturation also seems to suggest that the political and economical domains are peripheral to the function of the Church in society. One may observe, therefore, that inculturation is an aspect of liberation-the aspect which deals with the emancipation of culture under the inspiration of the Gospel. It is erroneous, therefore, to portray the theology of inculturation as an alternative to the theology of liberation. Cultural liberation is a subset of total liberation." This view is not convincing: "The question is no longer one of opting between liberation and inculturation. The imperative of incarnating or making contextual the Gospel message leads to a cultural creativity able to respond to the multi-sector challenges, integrating them into a symbolic, harmonic vision. The objective is not the inculturation for its own sake or for the sake of a special African contribution to humanity. Inculturation ought to aim at the life of communities and get interested in their promotion in the daily struggle for existence" (Ntakarutimana 2003:70).

${ }^{11}$ Kä Mana (1993:161-172), in addition to Old Testament texts (Gn 1-11; Ex 20: 2-17; Nah 1:7), uses New Testament passages (Mt 3:1-11; Lk 3:16-19; Jn 10:10; Rv 21:5) to support his reconstruction theology. After him, Manus might be the first to have come up with a more elaborate hermeneutical paradigm of "Jesus the constructor" (Manus 2003:113, 116), since Mugambi's model of reconstruction theology is Nehemiah: "The figure of Nehemiah becomes paradigmatically more relevant that that of Moses .... Nehemiah provides us with a mirror through which we can see our endeavours to rebuild Africa out of ruins of the wars against racism, colonial domination and ideological branding" (Mugambi 2003:128). In his model of reconstruction theology, Villa-Vicencio (1999:166) refers to Leviticus 25:1-55 and Matthew 25:31-46 for the empowerment of the poor and Luke 1:46-56 for the judgment of the strong.
} 
1998:143-144; Ndayango 2001: v 9, 2003:56). However, the model Manus uses seems to be more holistic as it integrates almost all the prominent African approaches. However, the issue of the epistemological value of intercultural exegesis still needs to be addressed.

\subsection{The epistemological value of intercultural exegesis}

Intercultural exegesis might have a similar epistemological foundation to cultural criticism, ${ }^{12}$ socio-scientific criticism, ${ }^{13}$ and inculturation hermeneutics. ${ }^{14}$ All these approaches have one important thing in common, namely a culture as a totality of a given human experience. Hence, culture is regarded as the most important factor in generating meanings. What are the criteria for valuable knowledge in intercultural exegesis? The present study uses two epistemological criteria for assessing the outcomes of an intercultural exegesis, namely respect for an African world view, as well as for Jesus' message.

\footnotetext{
${ }^{12}$ See Segovia (1995:7): "As a paradigm, cultural criticism may be summarized in terms of the medium or text as both medium and means, but with a much greater emphasis on the signified than on the signifier - the text as a message from author to readers within a given context, with an emphasis on the codes or principles governing the sociocultural aspects of such communication; hence, the text as a means to that word in which it was produced." Moore (1998a:20) coments: "One could argue that biblical cultural studies has emerged instead out of that sub-field of religious studies known (especially in the United States) as 'arts, literature and religion' - specifically, the analysis of how biblical scenes, themes, and stories have been represented in the traditional arts (visual and literary) and modern media (especially cinema)."
}

\footnotetext{
${ }^{13}$ See Elliott (2001:10): "As a component of the historical-critical method of exegesis, social scientific criticism investigates biblical texts as meaningful configurations of language intended to communicate between composers and audiences. With this method we set out to examine (1) the social features of the form and content of texts and the conditioning factors and intended consequences of the communication process; (2) the correlation of the text's linguistic, literary, rhetorical, theological-ideological, and social dimensions; and (3) the manner in which this textual communication was both a reflection of and response to a specific social and cultural situation -, that is, how it was designed to serve as an effective vehicle of social interaction and an instrument of social as well as literary and theological consequence." Craffert (2001:21) states: "The lifelong research program of Professor Bruce Malina can be characterized by a very legitimate problem: How to become a considerate reader of first-century Christian documents. In Malina's own words: 'I set as my task to lay out the meanings that emerge from reading pieces of a document, with an awareness of the cultural perspective that generated those meanings."
}

\footnotetext{
${ }^{14}$ See Ukpong (2000:24). Ukpong comments: "Inculturation hermeneutics ... seeks to redress the situation by adopting a holistic approach to culture whereby both the secular and religious aspects of culture are seen to be interconnected and as having implications one for the other, and the Bible is read within the religious as well as the economic, social and political contexts of Africa". See also Matand (1998:143-144) and Loba-Mkole (2004a:50): "Inculturation biblical hermeneutics can be regarded as an aspect of cultural criticism which emphasizes the reading 'in front of the text' while also using strategies from 'behind the text' and 'in the text' as well (cf West 1993:23-28, 42)".
} 


\subsubsection{African worldview: What promotes life is what is valuable}

African philosophical, religious, and ethical thoughts and practices are anthropocentric and life-oriented (Bujo 2003:33). Life is regarded as sacred, and every human and natural resource is encouraged to protect and intensify itself as much as possible. But, currently, in most practical situations, all aspects of this same life are made difficult by challenges and mishaps, as the implications for promoting life are diversely perceived. The contrast identified by Mugambi (2003:75) between a pedagogy of Liberation and a pedagogy of Reconstruction shows how the struggle for life is pulled in different directions:

\begin{tabular}{|l|l|}
\hline Pedagogy of Liberation & $\begin{array}{l}\text { Pedagogy of } \\
\text { Reconstruction }\end{array}$ \\
\hline Concentration on war & Concentration on peace \\
\hline Focus on the oppressor & Focus on the liberated agent \\
\hline $\begin{array}{l}\text { The oppressed as } \\
\text { objects }\end{array}$ & The liberated as subjects \\
\hline Emphasis on destruction & Emphasis on rebuilding \\
\hline Industry of weapons & $\begin{array}{l}\text { Industry of implements and } \\
\text { tools }\end{array}$ \\
\hline Regimentation & Decentralization \\
\hline Central command & Personal initiative \\
\hline Hierarchical leadership & Horizontal leadership \\
\hline Competition & Co-operation \\
\hline
\end{tabular}

At grass-roots level, that which promotes life in the African view includes progeny, wealth, good health and group-solidarity. Socially speaking, an honourable person in Africa is one who is able to raise a large family while displaying comfort, good health and solidarity. The latter is perceived as the greatest value in promoting life. Barrenness, sickness, unexpected death (after a short lifetime), and meanness put life in danger and need to be avoided. If life and protecting it are important values in Africa (as well as elsewhere), the epistemological value of intercultural exegesis in Africa (and elsewhere) can be measured by the degree of its commitment to promoting life, be it by using an inculturational, a liberational or a reconstructional approach.

\subsubsection{Jesus: What concurs with Jesus' message is what is valuable} Contextual hermeneutics in its epistemological endeavour ${ }^{15}$ focuses on the central role of compassion. It exposes the mentality conducive to the

\footnotetext{
${ }^{15}$ Epistemological endeavour refers to intellectual and practical efforts to be deployed for the "attainment of knowledge" (Van Aarde 1994:584).
} 
exploitation of power prevalent in ancient and modern societies. This hermeneutics is based on the radicality of the emancipatory living of Jesus of Nazareth. In this regard, the Jesus of history is the norm. As a matter of fact, the Jesus of history keeps us in touch with the radical dimension of Jesus' message, a dimension that can be easily lost as traditions and canons develop. In addition, the historical Jesus serves as reference for the reform and renewal of the tradition (Van Aarde 1994:584, 587).

Indeed, Jesus of Nazareth is seen as the "answer" or "solution" to issues and problems faced by theologians from both developed and developing countries. Various issues are viewed from the perspectives of Jesus' incarnation, crucifixion, ${ }^{16}$ death, resurrection, and eschatology, all pervaded by the role of his Father and his Spirit. Van Aarde (1994) shows how contextual theologies emphasised either the incarnation or the crucifixion of Jesus, because they are interested in a Jesus who suffers with the oppressed. However, recent "popular" contextual theologies are unabashedly propagating more and more a gospel of prosperity, anchored in the glory and honour of Jesus' divine sonship, his healing and miraculous powers to restore life whenever it is threatened. ${ }^{17}$

In epistemological terms, an intercultural exegesis in Africa needs to be measured against an African world view which values both the promotion of life and the message of Jesus regarding life, as it addresses shameful suffering and honourable situations.

Having discussed the definition, an existing model and the epistemological value of intercultural exegesis, it is time to apply this approach to two texts selected from the Lukan corpus.

\section{INTERCULTURAL EXEGESIS OF LUKE 22:69 AND ACTS}

\section{7:56.}

This intercultural exegesis combines three interpretative strategies set out above, namely reading "in front of the text" (reading in the African context), "in

\footnotetext{
${ }^{16}$ On the importance of the cross, see Quarshie (2000:22-23): "St Paul, the Hellenised Jew who took Christianity into the gentile world, may point to the right direction. That which was constant and non-negotiable for Paul was 'Christ and him crucified' with a theocentric base (1 Cor $2: 2 ; 1: 18) \ldots$ Thus, any idea or doctrine that would undermine Christ and Him crucified with its theocentric base and the monotheistic framework must be rejected by African Christian Theology." The Miracle Rock Deliverance Church in Bubuashie (Accra, Ghana) sees "the cross as a symbol of salvation and not as the means of deliverance or protection from sickness or bad omens .... Salvation, they believe, is through the acceptance of Jesus as one's Saviour, and trusting in him as the only deliverer" (Yeboah-Keyeame 2000:52-53).

${ }^{17}$ See Bate (1995:15): "Between 1980 and 1990 in South Africa, the number of Christians belonging to mainline churches such as Anglican, Methodist, Catholic and Dutch Reformed Church declined by 25 percent from 12.1 million to 9.1 million. During the same period the number of Christians belonging to those churches offering religious and faith healing increased by $23 \%$ from 5.6 million to 6.9 million.... The growth of the Coping-healing churches is probably one of the most visible phenomena in South African Christianity today."
} 
the text" (doing a literary analysis) and "behind the text" (doing a historicalcritical analysis).

\subsection{Reading in front of the text of Luke 22:69 and Acts 7:56: African communities}

\subsubsection{The contemporary situation in Africa}

According to Ndung'u (2003:262), one would have expected after attaining independence Africa would display a positive image after leaving behind its bitter historical experiences during the colonial era, but, in fact, the contrary prevails in many African countries. Africa is a sick, starved, bleeding and crippled continent crying for help from the West. Mugambi (2003:8) argues that, since independence, tropical Africa has been subjected to more internal destabilization and violence than ever before. Consequently, there has been an unprecedented internal and regional displacement of peoples and resources are being plundered. The few remaining resources and even the so-called aids are being diverted to deal with emergencies and to further ideological propaganda. There is no need to elaborate on the negative image of Africa that prevails all over the world, as a continent that is economically weak, politically mismanaged, socially fidgety, religiously gushing, and poor in all respects. The appalling poverty in most African countries seems to be the most conspicuous issue. Poverty relates to any situation that hinders a person or a group of people from satisfying basic needs like eating, drinking, sleeping, getting clothing, travelling, obtaining schooling, and working. ${ }^{18}$ This poverty is also used as the bottom line that can often be abused to feed other greedy needs.

What is positive about Africa? If a challenge can become an opportunity, then the very poverty that swamps Africa can be transformed into a venue of hope and elevation.

In her article entitled "Reading the Bible under a sky without stars", Tamez (2002a) uses the metaphor of abundance and the absence of stars to depict how contextual hermeneutics is developing in Latin America. The absence of "stars" refers to the situations of negation: where there is a lack of

\footnotetext{
${ }^{18}$ Poverty can also be defined in terms of "the emergence of large scale unemployment and the growing impoverishment of hundreds of millions of people" (Nürnberger 1999:3; see also Pieterse 2001:30): "Researchers are more or less agreed on the following definition of poverty: 'the inability of individuals, households, or entire communities, to command sufficient resources to satisfy a socially acceptable minimum standard of living' (May \& Govender 1998:27). The World Bank defines it in similar terms as the inability to attain a minimal standard of living. Ultimately the guideline to understanding what poverty means is the poor's own experience of it." Theuri (2003:230, 239) comments: "According to the 1997 Human Development Report of the UNDP, Africa is suffering under chilling destitution, characterized by poverty, oppression, violation of human rights ... . In global terms, the problem of poverty is one of the most serious challenges today .... It is important to realize that the situation of poverty calls for more than the reading of the Bible and other Church oriented texts. The social liberation of the poor and the oppressed thus becomes the core for each and every individual."
} 
love, justice, solidarity, jobs or peace. An abundance of "stars" relates to the feeling of completeness which gives Latin American people the strength for their struggle against injustices (Tamez 2002a:4-5). In another article, "A star illuminates the darkness", Tamez (2002b) interprets Luke 2 in the context of the first audiences as well as in the context of Latin America. In both contexts the poor people - shepherds in the Lukan audience and the present needy in Latin America - seem to be at the very centre of the Christmas message of peace and justice. They function not only as the receptors of the Gospel (the objects for the Good news), but also as the "evangelisers", or subjects of Gospel proclamation and interpretation (Tamez 2002b:57-58). Africa finds itself in a similar situation, where the upliftment of the poor requires their own commitment and co-operation. Hence, reading the Bible, including the narrative of Luke-Acts as well as the motif of Jesus' exaltation, constitutes an integral part of current culture in Africa.

\subsection{Lukan Christology and Jesus' exaltation in African communities}

\subsubsection{Jesus' birth as God's exaltation and honour for the poor people} (Lk 1-2).

The Lukan story of Jesus' birth can be viewed not only as an expression of God' glory, but also as God's intervention on behalf of the poor and the lowly, to raise them up, give them a new hope, and empower them to struggle for equality and justice in society (Ukpong 2002b:69). God is exalted because his action honours the poor people.

\subsubsection{Jesus' inaugural speech: The answer to the rejected (Lk 4:16-22)} Some of the Amawoti people who live in the KwaZulu-Natal Province (South Africa) conducted a contextual bible study on Luke 4:16-22 in October 1988. One member opened the session with prayer and introduced the topic, pointing out that the passage under discussion was Jesus' first sermon, which describes the purpose of his coming to earth. In the discussion between the members on questions related to the text, they came up with the following summary (West 1999:143-153, esp 153):

Jesus came

- for the rejected and neglected people $\mathrm{He}$ came with the answer to their problem

God's kingdom

- is where God's project is carried out:

- good news is coming to the poor

- the oppressed are liberated

- is people who build people 
In Amawoti, we see God's kingdom when:

- the community is organised

- they use good ways to meet their needs

- they make changes

- leaders are servants of the community.

It is interesting to notice that this summary was put up on the wall of the Ilimo project office. By doing so, this group was able to communicate with the target audience in a way that is accessible to the majority of the addressees, instead of in an academic format, which may reach only a few people.

\subsubsection{Lukan and Yoruba-Igbo Christologies (Luke-Acts)}

In a survey conducted by Manus (2003:183-204) among Yoruba and Igbo Christians in Nigeria, using English as well as local languages, eleven Christological designations provided answers to the question: "How do you recognize Jesus as you read Luke-Acts daily in your Church?" The Jesus of Luke-Acts was confessed as the Bearer of the Spirit, the Itinerant Good-Doer, the Prophet-Teacher, the Healer from Heaven, the Source of Life, the One ever in Our Midst, the Man of Prayer, the One who does everything for me, the Preacher of the Kingdom, the Owner of Victory, and Our Self-Sufficiency. The groups interviewed included men, women, and youths representing several Church denominations, such as Roman Catholics, Anglicans, Seventh Day Adventists, Baptists, Assemblies of God, and many other Revival churches.

A great number of local church leaders admired not only the salvationhistory in Luke-Acts, but also the way the first Christian communities were formed in Luke-Acts under the leadership of apostles, witnesses, deacons, prophets, elders and disciples. For them, the titles they ascribe to Christ are derived from the interaction between the reading of Lukan story about the first Christian communities and the life of contemporary Christian communities in Nigeria. Each christological title is emphasised by a particular church, according to its practices and expectations. It may happen that another title is cherished among members of a different church for socio-economic reasons. For example, the title "Jesus the Bearer of the Spirit", based on the accounts of Luke 4:16-22 and Acts 1:5; 2:1-5, is valued among Roman Catholics, Anglicans and Pentecostals who appreciate the role of the Holy Spirit in the life of Jesus and his followers. However, Christians affected by various diseases and hardships cling to the title "Jesus the Healer", regardless of their respective Church denominations (Manus 2003:201-204). 
The different readings of Luke-Acts by different African Christian communities underscore the relevance of the salvation story for audiences concerned with church management and caring for the poor. As Marshall $(1970: 92,94)$ has put it, "the idea of salvation supplies the key to the theology of Luke. Not salvation-history but salvation itself is the theme which occupies the mind of Luke in both parts of his work." Once Jesus has been identified as the saviour in the individual experience and community life of African Christians, the next step is no doubt the celebration, or rather, the exaltation and worship of the person of Jesus.

Jesus' exaltation in Africa is strongly reflected in songs of praise inside and outside Church institutions. Makoma, a Kinshasa-based Congolese music artistic group, is well known for its singing the praise of Jesus. The group competed in the seventh competition for the "Kora All Africa Music Awards", and won the prize for the best African group. On the same occasion Koffi Olomide (Kinshasa, Congo) whose song content and motivation are not explicitly the praise of Jesus, was applauded as the best artist from Central Africa, as the best African male artist, for the best video and received the special jury award. The event took place in Johannesburg, on 2 November 2002 and was broadcast on 77 television channels around the world (LobaMkole 2004b:69). In the last ten years, Kinshasa-Congolese Christian music, with its huge number of songs praising Jesus, are growing and glowing to the extent of outdoing some excellent cultural and popular songs. What remains is to inculturate such gorgeous and artistic ways of praising Jesus into other aspects of life.

The strategy of reading in front of the text indicates that the motif of Jesus' exaltation is known in African communities in spite of the challenges created in their lives by poverty. Some communities interpret Jesus' birth story as God's exaltation of and honour for the poor people (Lk 1-2). Others view Jesus' inaugural speech $(\mathrm{Lk} 4,16-22)$ as the answer to the problems of rejected people. After reading through the narrative of Luke-Acts, many more ascribe to Jesus several honourable titles which match up with the exaltation motif. Can the reading in the text of Luke 22:69 and Acts 7:56 confirm this exaltation motif already present in African communities' interpretations? 


\subsection{Reading in the text: Jesus' exaltation as the Son of man at the right hand of God}

\subsubsection{The literary genre of Luke-Acts}

Different genres have been identified for Luke-Acts, ranging from historiography, Graeco-Roman biography or novel.

Although the content of Luke-Acts is closest to history, its formal features do not exactly matches those of historical works of its time. As a Graeco-Roman biography, Luke-Acts may follow the three-fold pattern of this genre: the life of the founder, the disciples and successors, and the summary of the teaching of the school. This seems to be a very attractive and appropriate proposition for Luke-Acts, which offers many stories about the life of Jesus, his disciples and summaries of their school teaching. Another Graeco-Roman literary work that displays this pattern is Diogenes Laertius' Lives of Philosophers, "a lengthy compendium of the lives and teachings of eighty-two ancient philosophers from Thales to Epicurus, written ca AD 250 at earliest." ${ }^{19}$ In terms of the novel genre, many scholars have pointed out a generic relationship between Acts and ancient novels. In Aune's (1987) view, this case has been thoroughly argued by Pervo. According to Aune (1987:7980 ), Pervo argues that Acts lacks factual accuracy and suggests that it should be classified as a historical novel with a closer link to fiction than to history, and that its primary purpose is edification and entertainment. Five categories of episodes are similar to the ones found in ancient novels: arrests and imprisonments, persecution and martyrdom, mob scenes, trial stories, and travel and shipwreck.

For Aune (1987:138-139), the literary genre of Luke-Acts is an eclectic Hellenistic Christian general history narrating the early history of Christianity from its origins in Judaism with Jesus of Nazareth through to its emergence as

\footnotetext{
${ }^{19}$ See Aune (1987:79): “Talbert regards the similarities between Diognes' Lives and LukeActs as remarkable, for both contain the life of a founder of a religious community, a list or narrative of successors, and a summary of the community's teaching". However, Aune finds Talbert's analysis unsatisfactory for several reasons: only six of eighty-two lives have this pattern (Aristippus, Plato, Zeno, Pythagoras, Pyrrho, Epicurus), Diogenes is much concerned about people who studied with him rather than the legitimacy of their views or their commitment to assure an authentic tradition, as Talbert contends. Nevertheless, Aune (1987:79) recognizes that Talbert's proposal has the merit of attempting to find an analogy in genre to Luke-Acts as a whole.
} 
a relatively independent religious movement open to all ethnic groups. ${ }^{20}$ In this regard, Luke-Acts puts a great emphasis on the prophetic status of Jesus (Lk 4:24; 7:16, 39; 9:8, 19; 24:19; Ac 3:22-23; 7:37, 52). Aune contends that Luke uses several sayings from $Q$ to promote this view (6:22-23; 11:47-48, 49-51; 13:34-35): "Jesus is rejected and killed, not primarily because his words and behaviour antagonize Jewish authorities, but because he is a prophet of God" (Aune 1987:132). ${ }^{21}$ In a Jewish religious setting, a prophetic figure naturally enjoys a lot of admiration from the majority of the believers, since his words, deeds and symbols reveal God's salvation plan for his people.

\subsubsection{Literary Context of Luke 22: 69 and Acts 7: 56}

In Luke 22:69 and Acts 7:56 trial contexts are shown, one relating to Jesus' trial (Lk 22:14-71) and the other one to that of Stephen (Ac 6:8-8:1). As noted above, a trial is one of the literary motifs that fit into the broad literary genres used by the author of Luke-Acts. It is accommodated by the novel genre as well as by eclectic Hellenistic Christian history. Luke 22:69 is a key passage in Jesus' trial, while Acts 7:56 plays a similar role in Stephen's case. In their literary contexts, both logia seem to be used as evidence for the death penalty. As far as the literary links between Jesus' trial and Stephen's are concerned, the following literary structure has been pointed out (Gourgues 1978:186 n 14; Focant 1999:571):

\footnotetext{
${ }^{20}$ Luke-Acts is selective in the sense that it does not narrate all aspects of early Christianity from ca $4 \mathrm{BCE}$ to $A D 60$. It rather focuses on the mission and message of Jesus and the twelve apostles, which merged with the activity of Paul (cf Aune 1987:139).

${ }^{21}$ Jesus was killed, however, not only because he was the Son or the Prophet of God, but also because of the jealousy of the religious authorities (Mt 12:14; 27:18; Mk 3:6; 15:10; Lk 6:11) (cf Loba-Mkole 2004c).
} 


\begin{tabular}{|c|c|}
\hline $\begin{array}{l}\text { A. Elements common to } \\
\text { Matthew-Mark } \\
\text { 1. False testimony against Jesus } \\
\text { (Mt 26:59b,60b; Mk 14:56a,57a) } \\
\text { 2. Accusation relative to the } \\
\text { Temple (Mt 26:61; Mk 14:58) } \\
\text { 3. Behaviour of the accused: } \\
\text { silence of Jesus (Mt 26:63a; Mk } \\
\text { 14:61a) } \\
\text { 4. Accusation of blasphemy } \\
\text { (Mt 26:65b; Mk 14:64a) } \\
\text { B. Elements common to } \\
\text { Matthew-Mark-Luke } \\
\text { 1. Declaration of Jesus: } \\
\text { a. "The Son of Man ..." (Mt } \\
\text { 26:64a; Mk 14:62a; Lk 22:69a) } \\
\text { b. "... at the right hand" (Ps 110:1) } \\
\text { (Mt 26:64b; Mk 14:62b; Lk } \\
\text { 22:69b) } \\
\text { 2. Death of Jesus } \\
\text { "crying out in loud voice" (Mt } \\
\text { 27:50a; Mk 15:37a; Lk 23:46a) } \\
\text { C. Elements peculiar to Luke } \\
\text { Death of Jesus: } \\
\text { 1. Invocation of the Father } \\
\text { (23:46a) } \\
\text { 2. Reference to Ps } 31: 6 \text { (23:6b) } \\
\text { 3. Request of forgiveness for the } \\
\text { persecutors ( } 23: 34 a) \\
\text { 4. "when he had said this" (touto } \\
\text { eipōn) ( } 23: 46 c \text { ) }\end{array}$ & $\begin{array}{l}\text { Parallels in Acts } \\
\text { 1. False testimony against Stephen } \\
\text { (6:13a) } \\
\text { 2. Accusation relative to the Temple } \\
\text { (6:14a) } \\
\text { 3. Behaviour of the accused: } \\
\text { ecstatic silence of Stephen }(6: 15) \\
\text { 4. Accusation of blasphemy } \\
\text { (6:11b) } \\
\text { Elements in Acts } \\
\text { 1. Declaration of Stephen: } \\
\text { a. "The Son of Man ..." (7:56a) } \\
\text { b. “... at the right hand" Ps } \\
\text { 110:1) (7:56b) } \\
\text { 2. Death of Stephen } \\
\text { "crying out in loud voice" } \\
\text { (7:60a) } \\
\text { Parallels in Acts } \\
\text { Death of Stephen: } \\
\text { 1. Invocation of Christ } \\
\text { (7:59a) } \\
\text { 2. Reference to Ps } 31,6 \\
\text { (7:59b) } \\
\text { 3. Request of forgiveness for } \\
\text { the persecutors }(7: 60 b) \\
\text { 4. "when he had said this" } \\
\text { (touto eipōn ( } 7: 60 c) \\
\text { D. Elements peculiar to } \\
\text { Acts } \\
\text { 1. Vision preceding the } \\
\text { declaration ( } 7: 55) \\
\text { 2. Reactions from the } \\
\text { audience ( } 7: 57-58 a) \\
\text { 3. Presence and behaviour } \\
\text { of Saul (7:58b; } 8: 1)\end{array}$ \\
\hline
\end{tabular}

Brown (1994:485) argues that Luke's omissions from the Markan Jewish trial (no witness(es), no destruction of the sanctuary statement, no intervention by the high priest, no blasphemy charge, no formal sentencing) reflect an editing effort, and points out that much of this material is used in the Stephen trial in Acts 6-7. Some exegetes, without referring necessarily to Acts 7:56, view Luke 22:69 as a Christological and stylistic editing of Mark 14:62 (Radl 1988:143; Matera 1989: 529; Noël 1994:38; Elbert 2004:109). However, others assume that here Luke is using a non-Markan source (Légasse 1974:183; Soards 1987:103-104; Fitzmyer 1985:1458; Schneider 1988:117- 
118). Nevertheless, Focant (1999) continues to argue that the declaration of Jesus about the Son of Man does not spark the accusation of blasphemy, as is the case in other synoptic gospels. This accusation surfaces in the trial against Stephen as if the latter was the culmination and fulfilment of the trial started in Luke 22 (Focant 1999:573). ${ }^{22}$ Such a view needs to be substantiated more fully, since the deaths of Jesus and Stephen can be regarded as "historical" fulfilments of both trials.

One may also look at Stephen's trial as a literary hinge between Jesus' trial and that of Paul. At least, the presence of Paul is signalled during Stephen's trial (Ac 7:58b; 8:1). Moreover, Béchard (2003) has recently identified some literary parallels in the underlying tradition about Paul's trial: 1) Paul's arrest (Ac 21:27), which is a reminiscent of the earlier account of Stephen's arrest (6:8-15); ${ }^{23}$ 2) Jewish legal proceedings (21:28-29; 22:1, 22 $23)$, which are very similar to Stephen's trial in terms of the accusations typical of a "trial scene", ${ }^{24}$ the defendant's apologia (22:1, [3-21]), ${ }^{25}$ and the final verdict (22:22-23), ${ }^{26}$ and lastly Roman intervention, which does not appear in Stephen's case.

Furthermore, Focant (1999) holds that the standing position of the Son of Man is an invitation to Stephen to join him where it is possible to offer a true worship to God. At the same time, the salvation of Stephen coincides with the

\footnotetext{
${ }^{22}$ See also Taylor (2003:75-76): "It is widely argued that Luke deliberately transfers this charges from the trial of Jesus to that of Stephen. This is explained either in terms of a desire to avoid associating Jesus with the destruction of the Temple, or of locating references to this event at the point in the narrative where the transition to the Gentile mission is imminent .... This is better explained in terms of the subordinate Lukan addendum to dissociate Jesus from the destruction of the Temple."
}

${ }^{23}$ See Béchard (2003:246, n 56): "Both attacks are instigated by Jews from the Diaspora (cf Ac $6: 9 ; 21: 27$ ), whose similarly worded accusations (cf 6:13;21:28) result in the seizure of the accused (cf 6:12; 21:27), an unsuccessful defence speech (cf 7:2-60; 22:1-21), and a cry of protest from the assembled crowd (cf 7:57; 22:22-23)."

${ }^{24}$ See Béchard (2003:247, n 59): "The accusation made against Paul by the Jews from Asia, like the one against Stephen during his trial before the Sanhedrin, begins with a formula of identification houtos ... ho anthrōpos ..., Acts 21:28; cf ho antthrōpos ... houtos ..., 6:13) appropriate to a legal proceeding. So Schneider, Apostelgeschichte, 2.313."

\footnotetext{
${ }^{25}$ See Béchard (2003:247, n 60): "In his opening words, Paul explicitly identifies the speech to follow as an apologia (Ac 22:1), a term that in its technical sense refers to a formal defense speech delivered at a trial (see 24:10; 25:8,16; 26:1, 2,24; see also Plato Apol. 28A; Phaedr. 267A; Josephus Ap. $2.14 \S 147)$. It may be noted that in addressing the crowd as Andres adelphoi kai pateres (Acts 22:1) Paul repeats a form of address used earlier by Stephen at the beginning of his speech before the Sanhedrin (see 7:2)."

${ }^{26}$ See Béchard (2003:247, n 61): "As Cadbury (Dust and Garments, 275-76) has pointed out, the verb rhiptō is used by the author to signify the act of 'casting off' (Luke 17:2; Ac 27:19, 29) or 'throwing down' (Lk 4:35), and its use in Acts may be fairly compared with the laying aside of garments during the stoning of Stephen in Acts 7:58."
} 
judgment of his opponents who rejected Jesus and his disciples (Focant 1999:570, 576). In addition, Focant $(1999: 570,576)$ contends that the Son of Man 's sayings peculiar to Luke support the meaning of the Son of Man as the saviour, judge and the defender of the elect. ${ }^{27}$ The perception conveyed about Jesus by Luke 22:69 and Acts 7:56 as eschatological saviour, judge and defender, coupled with the portrayal of his earthly life as a mighty prophet (Lk 24:19) could lead his followers to do nothing less than admire and exalt him.

Such an interpretation needs to address the historical background of the communities that produced the texts. Before dealing with historical insights, however, it is important to grasp the linguistic meaning of the texts concerned.

\title{
3.2.3 Linguistic analysis of Luke 22:69 and Acts 7:56.
}

The results of research about the relationship between Luke 22:69 and Acts 7:56 are well summarised by Dillon (1990:742):

\begin{abstract}
Remarkable for both this "standing" posture and for being the very rare Son-of-Man saying on other than Jesus' lips, this word of the martyr is likely Luke's variation on Luke 22:69 in further elaboration of v 55 (so Conzelmann, Schneider, Weiser, Sabbe, Mussner). "Standing" may bespeak the Lord's welcome to his martyr in an individualized parousia (Barret), or his intercession for the confessor true to Luke 12:8 (Schneider), or his exercise of judgment against recusant Jewry (Pesch); or, least plausibly, it could be a "meaningless" variation upon the risen One's sitting at God's right hand (2:33-35; Mussner, Sabbe).
\end{abstract}

Focant (1999) supports the majority of the opinions expressed below, although he emphasises polysemous meanings for Acts 7:56, as indicated in the introduction of this study. Denaux (2002a:128,140,142; 2002b:55;

2003:222) sides with the minority of those views which do not see a significant difference between Jesus' being seated or his standing, but insists on the sharing of God's lordship by the risen Son of Man in both Luke 22:69 and Acts 7:56. This view seems to me to be more appropriate. The previous section has shown that the trial motif constitutes one of the prominent literary genres used by first century Graeco-roman writers, including the author of Luke-Acts. It so happens that the texts of Luke 22:69 and Acts 7:56 depict the literary context of a trial, in particular the trial of the protagonist.

\footnotetext{
${ }^{27}$ Focant (1999:572-573) argues that if one considers passages that are found only in Luke, it appears that in Luke the Son of Man comes as Saviour (Lk 19:10), in his heavenly status, judge and defender of his elects (Lk 18:7-8). Furthermore, every decision taken against or in favour of Jesus has an eschatological consequence, as it will serve as criterion of judgment during the manifestation of the Son of Man (Lk 12: 8-9).
} 
A contrastive linguistic analysis might shed some light on how to understand the meaning of Son of Man in Luke 22:69 and Acts 7:56. Luke 22:69 reads as follows: apo tou nun de estai ho huios tou anthrōpou kathēmenos ek deksiōn tēs dunameōs ("but from now on the Son of Man shall be seated at the right hand of the power"). The text of Acts 7:56 appears in the following wording: kai eipen, idou theōrō tous ouranous diēnoigmenous kai ton huion tou anthrōpou ek deksiōn hestōta tou Theou ("and he said, 'Behold, I see the heavens opened, and the Son of Man standing at the right hand of God'").

The most striking similarity between Luke 22:69 and Acts 7:56 relates to the use of the phrase "Son of man". In both cases, "Son of Man" is used about the protagonist of the scene, namely Jesus in Luke 22:69 and Stephen in Acts 7:56. However, this similarity is more obvious at the lexical level. At the grammatical level, there is some dissimilarity, since in Luke 22:69 is the subject of the verb estai (will be seated), while in Acts 7:56 it appears as a second complement of the object of the verb theōrō (I see). This is a first significant demarcation regarding the phrase "Son of Man" in Luke 22:69 and Acts 7:55.

To shift from Luke 22:69, Ac 7:56 echoes Mark 14:62 in terms of its grammatical construction, as in both cases, "Son of Man" is the object of a verb of sight (cf opsesthe in Mk 14:62 and par Mt 26:64; and theōrō in Ac 7:56). In Mark 14:62, "Son of Man" is used in a circumlocutional sense, indicating a self-reference from the speaker. In this case, the speaker is Jesus. I had elsewhere argued that in Mark 14:62 the phrase "Son of Man" refers not only to the speaker Jesus, but also portrays him as a human being: "This aspect becomes more important in the context of [Mk] 14:62 where Jesus has just affirmed himself to be the Christ, the Son of God. By using 'Son of Man' instead of 'me' he claims to be not only the Christ, the Son of God, but also a human being" (Loba-Mkole 2000a:1132).

Is it possible that the meaning of Mark 14:62 could have been shared in Luke 22:69 and Acts 7:56? Answering this question is a very tricky exercise, since "yes and no" can apply to both cases. On the one hand, it can be argued that Luke 22:69 shares the meaning of Mark 14:62, because the circumlocutional use of the phrase Son of Man is justified in both cases, as well as in Matthew 26:64. In all these three contexts, the protagonist of the trial story is a same human speaker: Jesus. Although the story is written after Easter experience, the trial narratives strive to account for some core events before Easter. On the other hand, Luke 22:69 might not share the meaning of Mark 14:62, as it deviates from the latter in terms of the grammatical construction, which makes Son of Man the subject of a verb. Therefore, since Acts 7:56 is closer to Mark 14:62 in view of a similar grammatical construction, 
one might argue that the two can have the same meaning. However, the circumlocutional use of the phrase "Son of Man" is not obvious in Ac 7:56, given that the author would hesitate to have Stephen referring to himself as standing on the right hand of God.

If the circumlocutional sense is doubtful in Acts 7:56, does the term "Son of Man" here have a generic meaning (that is, a human being) as in Mark 2:28 (Bultmann [1948] 1984:30) or even an indefinite meaning (someone)? None of these meanings seems to fit in this context. Since Stephen's audience or at least the author of his trial story would be aware that Jesus used to call himself "Son of Man", it is more likely that this phrase (Ac 7:56) refers to Jesus in the sense of his own nickname by which his disciple Stephen wanted to relate to him more intimately:

In form it appears to be an appellative, either a title comparable to "the Son of God" and "the King of Israel", or a nickname like one Jesus is reported to have given James and John, 'Sons of Thunder' (Mk 3:17). In function, however, it serves neither as a title nor as a nickname; that is, it is not used by others, whether as a form of address or as a means of specifying his function in statements about Jesus.

(Hare 1983:1)

In some places in Africa, anybody, and especially a friend, can call a person by a nickname which she or he has given to herself or himself. For instance anyone, including Dodge Kiunyu himself, would call him by the nickname "Son of woman" (Mungua [1988] 2000:1, 9). By using this nickname, Kiunyu certainly wants to underline his solidarity with humankind, and especially with women. Contrary to Hare's argument, it seems that the term "Son of Man" in Ac 7:56 would function as a nickname used by an individual to refer to his friend who was known to have used that phrase as an idiom of autoreference.

A second demarcation concerning the use of the phrase "Son of Man" in Luke 22:69 and Acts 7:56 consists of the well-known contrast between the participles portraying him as sitting in Luke 22:69 or as standing in Acts 7:56. The reference to a seated position is shared by Mark 14:62, Matthew 26:64 and Revelations 14:14, while the standing posture is peculiar to Acts 7:56. The similarity between the synoptic gospels and Revelations 14:14 is very interesting and yet problematic. Revelations $14: 14$ is in agreement with the synoptic gospels regarding the seated posture, but it differs from them on two lexical levels. On one hand, "Son of Man" in Revelations 14:14 does not have a definite article, and it is used with a simile (homoion = like; cf $k^{e}$ bar nash in 
Dn 7:13). This passage is problematic especially for those exegetes who contend that the term "Son of Man" in the New Testament has a titular and messianic meaning because of the double determination. In Revelations $14: 14$, the definite article ho/ton (the) before huios/huion (son) and the awkward genitive form tou (of) in front of anthrōpou (man) are all removed. Moreover, some might argue that "Son of Man" in Revelations does not refer to Jesus, because the term lacks the double specification. As a matter of fact, "Son of Man" in Revelations 14:14 (cf also Rv 1:13) is found in the context of a vision where the beneficiary is contemplating the exalted Jesus in heaven. The content of the vision evokes scenes of trial and judgement (Rv 1:9-20; 14:14-16; see also Jn 5:27). Therefore, the announcement about seeing the Son of Man sharing God's lordship in Mark 14:62 seems to be accomplished to some extent in the visions of Acts 7: 56, Revelations 1:13 and 14:14-16, as indicated by the contrast between the future opsesthe in Mark 14:62 and the present theōrō in Ac 7:56 or the aorist eidon in Revelations 14:14.

In Biblical literature, a true vision has often been a sign by which God authenticates the message of his true prophet (Dapila 2000:16; Loba-Mkole 2004b:71). According to Koet (1999:757), the disciples of Jesus, like the prophets, need visions to tell them how Jesus' mission is to be followed by their mission. In this respect, Stephen in Acts 7:56 and John in Revelations $1: 13$ and 14:14 would feel deeply honoured by being allowed to "see" Jesus' sharing God's lordship. At the same time, their respective audiences are comforted or concerned. According to Malina and Pich (2000:38-39, 187; also De Villiers 2004:237), what John sees is a "constellation in human form [= the cosmic Jesus] amid the seven planets, clearly something of concern to the human beings on the land below."

The following section will try to examine from historical perspectives how the phrase "Son of Man" fitted Jesus and how important the categories of shame and honour were in the persecution contexts of the first century Graeco-Roman World.

\subsection{Reading behind the text: the first century Graeco-Roman world}

\subsubsection{Religious persecution}

It is highly likely that the trials of Jesus and Stephen took place in Jerusalem: "Jerusalem was the place of Jesus' death and burial" (Mk 14:43-16:8). Largely on this account, later Christians came to see the destruction of Jerusalem in 70 CE as a sign of God's judgment upon the city (Tertullian, Apol 26; Origen, Cels 8; 22; Cyprian, in Iud 12; Lactantius, Epit 48; Eusebius, HE 3.5; cf Barn 16; Ps-Clement, Recog 14) (see Taylor 1999b:447). Although Jesus' trial as 
depicted in the Lukan Gospel does not mention the destruction of the Temple as a charge against him, it is arguable that for the first Christians the Temple was an institution under judgment, since its destruction had been proclaimed by Jesus in his eschatological discourse (Lk 21:20-38). Therefore, the expectation of the destruction of the Temple might have been associated with Christian eschatological expectations. The destruction of the Temple was expected to be the sign of Jesus' second coming (Taylor 1999b:457). However, the emperor Caligula's intended appropriation of the Temple might have acted as a catalyst for the destruction of the Temple.

Consequently, in his repudiation of the Temple and Temple cult, Stephen held views broadly in line with both Palestinian "Hebrew" and Diaspora "Hellenist" Christian opinions. Most interestingly, Taylor argues that it was not the content of Stephen's views, as reflected in Acts 7, that precipitated his death, but rather the context in which they were expressed. ${ }^{28}$ In the Lukan account of Jesus' trial, the latter was killed as a prophet of God, but not as "a divinely Son of Man". Similarly, Stephen was killed not because he confessed Jesus as the "divinely Son of Man", but rather because of his association with Jesus Christ in a context of the persecution against the first Christians. However, it is important to understand the term "Son of Man" from an historical perspective.

\subsubsection{The "Son of Man" as an historical figure}

"Son of Man" can be correctly understood as an expression used by Jesus to refer to himself as a human being. This is based on the linguistic origin of the expression referring to a human being and on the findings from the history of religions, as well as from the Gospel of Mark and the source $Q{ }^{29}$

In African contexts, some people, for example, the Congolese musician artists Mbilia Bel, Koffi Olomide, Madilu Système, and others, refer to themselves using the terms "mwana wa moto" ("Son of Man/woman or daughter of man/woman"). Similarly, a Kenyan novelist refers to himself as a "son of woman" (Mungua [1988] 2000). Generally speaking, ordinary African

\footnotetext{
${ }^{28}$ See Taylor (2003:84): "Whether this context is to be identified as the Hellenistic synagogues jealous of the sanctity of the temple, or as the situation of heightened tension in the face of Caligula's threat, which brought persecution upon other Palestinian Christians also, it was these circumstances and not any distinctiveness in his theology, that exposed Stephen to persecution and martyrdom."

${ }^{29}$ See Taylor (1999a:152): "That 'ho huios tou anthrōpou' was not the formal title of an eschatological figure, either in the Gospels (Perrin 1963; 1967; Vermes 1973; 1978; Casey 1979; Lindars 1983) or in the Similitudes of Enoch (Casey 1979:100-102; Nickelsburg 1981:215; Collins 1984:112) is now generally recognized. The phrase is clearly circumlocutory ...." (see also Loba-Mkole 2003:837-858).
} 
audiences understand "Son of Man" as an idiom denoting a speaker who is a human being.

Except for some Jewish rabbis who have used the Aramaic hahu gabra (that man) and bar nash to refer to themselves, Jesus of Nazareth seems to be the only historical and religious person who has used the term "Son of Man" in the circumlocutional sense in addition to the generic and indefinite sense (Vermes 1967:320, 327; Loba-Mkole 2000b:557-566). However, none of the New Testament sayings has unequivocally been proven as being an authentic utterance of Jesus. In the light of the criterion of multiple attestation and dissimilarity, one can merely make an educated guess that Jesus did in fact use the "Son of Man" expression as an auto-reference, although the authentic wording might have been lost or placed in different contexts by the gospels writers. According to Tuckett (2001:390), ascribing term "Son of Man" to the "historical" Jesus seems entirely appropriate.

From a historical viewpoint, the Jesus who might have referred to himself as the "Son of Man" is known as a Jewish charismatic religious man, teacher, prophet, or wise man. He was born in circa 4 BCE, near the time of the death of Herod the Great, and spent his childhood and early adulthood in Nazareth. John baptized him. This event is seen as a turning point in Jesus' life. He called together disciples, and proclaimed the Kingdom of God in the towns, villages and countryside of Galilee. When he was about 30 years old, he undertook a journey to Jerusalem for the Passover and created a disturbance in the Temple area. He had a final meal with the disciples, was arrested and interrogated by Jewish authorities, especially the high priest. He was executed (crucified) on the orders of the Roman prefect, Pontius Pilate. His disciples at first fled. They saw him (in what sense is not certain) after his death. As a result, they believed that he could return to found his kingdom and they formed a community to await his return and sought to win others to faith in him as God's Messiah (Sanders 1993:10-11; Van Aarde 2001:59).

According to Van Aarde (2001:46), Jesus grew up as a fatherless child. In first-century Galilee, fatherless children were marginalized and not considered children of God. Yet Jesus' followers considered him to be precisely that - the child of God. Consequently, New Testament writings apply the metaphor "Son of God" to Jesus in the light of his experience as that of being a child of God. They use this metaphor to signify Jesus' unmediated access to God in terms of divine origin and power. The combination of divine origin and power is supported by the stories of a miraculous birth, wondrous deeds, death, resurrection and ascension.

During New Testament times, portrayals of divine birth and adoption were well known, for instance, in the myths surrounding Hercules, Perseus, 
Horus and Priapus. Among these figures, Hercules stands out, not only because of his divine conception, but also for having been adopted as child of Zeus when he conquered death. Paul's Jesus was a Hercules figure who, on account of his victory over death through resurrection, was publicly and strongly declared to be God's child. Luke might have been influenced by this idea, but he ascribes Jesus' divine Sonship to his conception (Van Aarde 2001:165,198). It is indeed this very fatherless child Jesus, child and Son of God, who used to call himself "Son of Man". It is astonishing to note that the concept "Son of Man" was exegetically and perhaps wrongly associated with mythological divine figures in the ancient religions from the Middle East, whereas the title "Son of God" is evidenced in the Greek myths. Jesus might be the only historical figure accorded both the "Son of Man" and "Son of God" appellations, though in the former case, he used the appellation to refer to himself, whereas the latter was a confession from his followers.

It is this Jesus, a historical figure who used to call himself Son of Man, ${ }^{30}$ who was persecuted and killed (Lk 22-23), and his disciple Stephen received a same treatment (Ac 6:8-8:1). Christian persecutions during the first century Graeco-Roman world might have been shameful as well as honourable.

\subsubsection{Honour and shame in relation to the Son of Man}

Due to the possibility of religious persecution, some of Jesus' disciples were certainly inclined to deny him. As a matter of fact, Luke 12:8-9 is a record of such a possibility.

Bultmann ([1948] 1984:30, 31; see also Hahn 1963:33) had classified this logion among the authentic ones, which distinguish between the historical Jesus and the eschatological Son of Man, whom the historical Jesus was also expecting to come. However, while they do consider Luke 12:8-9 authentic, other critics do not accept Bultmann's distinction between Jesus and the coming Son of Man. Instead, they see this distinction as one between two

\footnotetext{
${ }^{30}$ Marcus (2003: 384-386) interprets "the Son of man" as the "Son of Adam" or the "New Adam" in his humiliation and splendour: "In fact, one of the great advantages of the figures of Adam for the Gospels' Christology is that he holds together in one person both the splendour and the humiliation that are so central to the early Church's picture of Jesus. If the 'Son of Man' is the new Adam, then the Jesus of the Gospels presents himself as the founder of a new humanity and depicts the Endzeit, in which he is carrying out his ministry, as the recapitulation and perfection of the Urzeit .... The exaltation of Adam is tied to the exaltation of the second Adam." Interpreting "Son of man" in terms of "Son of Adam" sounds like a tautology. Similarly, it seems anachronistic to hold that "the exaltation of Adam is tied to the exaltation of the second Adam" (the Son of Man).
} 
functions or statuses of a same person, Jesus. ${ }^{31}$ Although Vaage (1991:126) attributes Luke 12.8-9 to $Q^{2}$ (a redactional addition) that emphasises the eschatological Son of Man, while the first or most authentic stratum $\left(Q^{1}\right)$ deals with violence $(7: 34 ; 9: 57-58)$, Vögtle (1994:177-178) still considers it as a key logion ("das Schlüsselwort Lk 12, 8"). For the latter exegete, this logion not only preserves an authentic record, but it also indicates in which sense Jesus used the "Son of Man" saying to express his function of Judge and end time saviour (see already Lührmann 1969:40; Hoffmann 1982:156; 1995:208). ${ }^{32}$ We prefer to focus on the historical context that might have favoured this saying.

In the Gospel of Luke, this logion appears in the context of a warning against hypocrisy (12:1-3), as well as of an exhortation of not fearing people who kill the body $(12: 4-7,10-12)$. The mention of trials before the synagogues and the rulers clearly alludes to a historical context of persecution. Matthew's version (Mt 10:32) is also intercalated in a context of persecution that the disciples are likely to face during their mission (Mt 10:1-42). However, the Markan account (Mk 8:38) is placed in the context of Jesus' passion prediction, followed by a clarification about the meaning of the discipleship (Mk 8:31-38). This includes bearing someone's own cross and not being ashamed of confessing Jesus in this sinful generation. Mark is the only gospel that obviously refers to the shame that the disciple will have to face if he or she is ashamed of Jesus. Nevertheless, even in Matthean and Lukan parallels, the act of confessing the disciple's master in front of other people (friends and especially enemies) can surely be interpreted as an honourable gesture, both for the disciple and for the master, while the contrary is shameful. The warning against fear and shame which may invade disciples' hearts, especially during a time of persecution is a serious matter, as the future of Jesus' Gospel depends on a courageous and honourable witness. Furthermore, Malina and Rohrbauch (1992:271) regard Mark 14:53-65 as depicting 'what the anthropologists call a 'status degradation ritual', in which the honour and public standing of a person is fatally and irreversibly undermined."

\footnotetext{
${ }^{31}$ Vögtle (1994:147-148) distinguishes between "dem irdischen" and "dem erhöhten Jesu Christi". Along the same lines, see Vielhauer (1965:107), who speaks of "nicht zwei Personen, sondern zwei status derselben Person", followed by Conzelmann and Lindemann (1987:110) for whom this distinction represents "zwei Epochen des Wirkens derselben Person". Lohse (1984:49) presents a similar consideration: “... nicht von zwei Personen die Rede, sondern werden die irdische Wirksamkeit Jesu (= Ich) und sein Kommen in messianischer Herrlichkeit (= Menschensohn) einander gegenübergestellt."

${ }^{32}$ Borsch (1992:144) has the same idea: "Lk 12:8-9 is a critical passage for anyone trying to understand the Gospels' Son of Man."
} 
Besides the grammatical links, the theme of honour seems to be tying together the occurrences of the phrase "Son of Man" in Acts 7:56, Mark 14:62, Revelations 1:13, and 14:14. Moreover, there are some temporal connections between these texts, since they might have been written during the same period, that is, before the fall of the Temple (70 AD) and the time of emperor Nero (54-64 AD), to whom the author of Revelations refers by the symbolic number 666 (Rojas-Flores 2004:375-392; see also Moberly 1992:376-393; Wilson 1993:587-605; Slater 2003:252-258).

\subsubsection{The importance of shame and honour in the first-century Graeco- Roman world}

Malina (1993:67) describes an individual of the first century Mediterranean world as a strongly group-oriented person, a group-embedded person, a collectivity-oriented person or a dyadic person, as opposed to an individualistic person. He or she conceives himself or herself as always interrelated with other persons, both horizontally (with others who share the same status) and vertically (with others who are above and below that person in social rank). Such a person needs others continually in order to know who he or she really is, and his or her pivotal values would be honour and shame, not guilt. ${ }^{33}$ Honour and shame play an important role in the identity of dyadic persons because they perceive themselves and form their self-image in terms of what others perceive and feed back to them. In other words, they feel they need others for their very psychological existence, since the image they have of themselves must agree with the image formulated by significant members of their family, village, city or nation.

As far as Jesus and the first Christian communities are concerned, traditions indicate that Jesus formed a faction with twelve symbolic helpers to proclaim the kingdom of God and to heal in the name of God of Israel, who he addressed as Father. Following Barr (1988:28-47), Malina (2001:141-142) underscores that the Aramaic Abba did not mean Daddy, as it does in modern Hebrew: "Both in New Testament translation (Abba = ho Pater; Mk 14:36; Rm 8:15; GI 4:6) as well as from grammatical construction, Abba means father, a term of respect and honor." Indeed, Jesus proclaimed the kingdom of God looking upon God as Father and announcing "a political, political religious, and

\footnotetext{
${ }^{33}$ For Botha (2000:269): "Honour and shame are variously described as 'pivotal' (Malina 1981:25) or 'core' (Plevnik 1998:106) or 'central' (Moxnes 1996:33)." See also Stiebert and Walsh (2001:123): "The honour-shame model came to prominence in Mediterranean socioanthropological studies during the 1960s. Particularly since the late 1980s it has been widely applied to social reconstructions of the Biblical world. This model defines honour and shame as the pivotal social values and constant preoccupation of the small-scale, face-to-face communities of the Mediterranean basin. In these communities an individual's moral obligations are depicted as concentrated primarily within the family. Outside of this circle, interaction is often marked by distrust and competition."
} 
political economic theocracy to Israel" as a solution to Israel's problems. Jesus' followers would compare his solution with other available solutions, like the ones proposed by the Pharisees, the Sadducees, the Herodians, the Essenes and other groups. Jesus' followers might have found his solution more attractive, since "comparative archaeological evidence suggests that the unrest characteristic of Israel during the first part of the first century was due to unwillingness on the part of Israelite aristocratic elites to function as patrons for their fellow Israelites in favour of expanding their own elite standing" (Malina 2001:141). In such a situation, the solution that Jesus proposed in terms of God as Father or Patron was relevant and most welcome. Jesus' own group, which was a social movement organisation - according to Malina - worked to change "elements of the social structure or reward distribution, or both, of a society". However, the Jesus Messiah groups, which are more fully described in the early chapters of Acts, expected such changes to happen when Jesus would return as the Messiah with power - as a political leader (Malina 2001:153).

In an economic sense, the changes that Jesus' social group was aiming at could have been governed by the following principles: the wickedness of the wealthy and the common-sense observation that no one should die or suffer for lack of the necessities of life. In fact, the proclamation of the Kingdom of God with God controlling his own land in the sense of the Torah jubilee would entail the redistribution of wealth in Israel and a restitution on the part of the wealthy Israelites. Moreover, a peasant society like the one of Palestine in Jesus' time perceived the majority of people as neither rich nor poor. They were rather seen as equal in that each had a certain status to maintain in some honourable way (Malina 2001:100, 111). Nevertheless, practically speaking, in in Jesus' time, there were poor people in the sense of being "socially impotent" and rich people who were perceived as "greedy and avaricious" (Malina 2001:110). These rich people were also amassing wealth in order to maintain their "own honour among their peers", but not in the view of the majority.

In a nutshell, Jesus' teaching might have been perceived by his social group, as well as by the Messiah group, as an encouragement for the majority to live in an honourable way, including in socio-economic terms. Such perceptions would surely have prompted some excitement in the hearts of his followers and would have strengthened the motif of his exaltation.

\section{CONCLUSION}

Jesus' figure was exalted, worshipped in the early Christian communities not only on the grounds of his perceived role as eschatological saviour, judge and defender, but especially because of the hope of salvation that he had aroused 
in the hearts of his followers, including in socio-economic terms. Luke 22:69 and Acts 7:56 stress that the exaltation of Jesus took place in a context of trials and persecutions.

A linguistic analysis has shown some strong grammatical links between Acts 7:56 and other texts beyond Luke's works, especially Mark 14:62, Revelations $1: 13$ and 14:14. All these texts are connected by the use of the verb expressing the sight (horaō or theōrō), but when Mark 14:62 announces seeing the "Son of Man", similar occurrences in Acts 7:56, Revelations 1:13 and 14:14 convey the completion of that seeing in some visions. The beneficiaries of these visions and their respective Christian audiences are certainly comforted and honoured.

The courage of Jesus in maintaining his religious identity during his trial and persecution (Lk 22:69; cf Mk 14:62; Mt 24:64), as well as the witness of Stephen in parallel circumstances (Ac 7:56), serve as models for early Christian communities. Such models became more relevant to them as they continued to proclaim the Gospel of Jesus amidst persecution and socioeconomic hardship.

Even more striking is the fact that Luke 22:69 (and also Mk 14:62), which shows an awareness of Jesus' incarnation and resurrection, depicts him as reiterating his human identity by referring to himself as "Son of Man". $\mathrm{He}$ is later seen as sharing God's lordship (Ac 7:56; Rv 1:13; 14:14). This reference would have had a great impact on Jesus' followers, who are human beings, as they see him associating himself with them, and emphasising his solidarity with them. ${ }^{34}$ Early Christian communities would surely have understood Jesus to have been using the epithet "Son of Man" as a personal nickname to confirm his human nature and express his solidarity with human beings. His exaltation would then flow naturally from the hearts of his

\footnotetext{
${ }^{34}$ Marcus (2003:383) comments: "He (Jesus) is also, to be sure, a figure who is strongly associated in other traditions with human misery, suffering, and death, and even with death. In fact, one of the great advantages of the figure of Adam for the Gospels' Christology is that he holds together in one person both the splendour and the humiliation that are so central to the early church's picture of Jesus". According to Marcus, some passages in the Gospels (Mk 2:10; 2, 27-28; 10, 45; Mt 24, 27//Lk 17:24; Mt 25, 31-46; Jn 5, 26-27; 6, 27) confirm that "Son of man" means "Son of Adam"; and "this does not mean that Jesus as Son of Man is merely human, since Adam is a figure of great glory, even godlikeness, in some of the traditions upon which the Son of Man sayings draw (see Gn 1:26-27; b Pes 54a Gen Rab 8.10 21:5; Gn 3:22; Gn Rab 21:1.7." Jesus' status as more than a human being cannot be based on the glory of Adam, since Adam figures as no more than a human being. More interestingly, Jesus as the Son of Man is a "revealer and catalyst of our true humanity" (Wink 2002:260). Odoemene (2003: 38) views Jesus as an African Christian Point of Self Awareness, and considers the Son of Man not simply as a heavenly person. He rather acquired his glory through suffering and death: "The Lord and Christ is the point of self awareness and orientation, a guideline and the principal motivator of every good act, thus a source and point of self-awareness that would lead to liberation."
} 
followers, besides the respect and admiration of other people, including the ones who were involved in planning his death. ${ }^{35}$

Similarly, the worship and exaltation of the name of Jesus in Africa is seen in the context of persecution, though all such persecution is not strictly of a religious nature (much persecution in justified on ethnic and political grounds). However, this does not undermine the importance of these persecutions, since, even in Jesus' case, the motive for demanding the death penalty for him before the Sanhedrin or Pilate was more political than religious. Moreover, Africa finds itself in a socio-economic crisis similar to that experienced by early Christian communities. In such a context, solidarity plays a great role, not only as a traditional and moral value common among grouporiented persons, but also as a tool for survival in the face of socio-economic challenges. Since the Gospel of Jesus expresses his solidarity with persecuted and underprivileged people who long for salvation, as many Africans do, it is no wonder that admiration for him and his exaltation are blooming in Africa.

\section{Works consulted}

Aune, D E 1987. The New Testament in its literary environment. Philadelphia, PA: Westminster.

Barr, J 1988. Abba isn't "Daddy". Journal of Theological Studies 39, $28-47$.

Bate, S C 1995. Inculturation and healing: Coping-healing in South African Christianity. Pietermaritzburg: Cluster.

Béchard, D P 2003. The disputed case against Paul: A redaction-critical analysis of Acts 21:27-22:29. Catholic Biblical Quarterly 65(2), 232-250.

Bediako, K 2000. A half century of African Christian thought: Pointers to theology and theological education in the next half century. Journal of African Christian Thought 3(1), 5-11

Bediako, K 2001. Scripture as the hermeneutic of culture and tradition. Journal of African Christian Thought 4(1), 2-11.

Bieringer, $\mathrm{R}$ et al (eds) 2002. Resurrection in the New Testament. F S J Lambrecht. Leuven: Leuven University Press. (Bibliotheca Ephemeridum Theologicarum Lovaniensium 165.)

Bird, A et al (eds) 1996. "Reading with": An exploration of the interface between critical and ordinary readings of the Bible: African Overtures. Atlanta, GA: Society of Biblical Literature. (Semeia 73).

Black, M (ed) 1967. An Aramaic approach to the Gospels and Acts. 3rd ed. Oxford: Oxford University Press.

\footnotetext{
${ }^{35}$ Compared for instance to Sennacherib, an Assyrian king who was depicted as a man of great honour, but died of a shameful death after his unsuccessful attempt to defeat Jerusalem (see Prinsloo 2000:348-363), Jesus was a humble man, though a mighty prophet who was more exalted after his death and resurrection, as well as upon the account of the exemplarity of his early life.
} 
Borsch, F 1992. Further "reflections on "The Son of Man": The origins and development of the title, in Charlesworth, $\mathrm{J} \mathrm{H}$ (ed), The Messiah: developments in earliest Judaism and Christianity, 130-144.

Botha, P J 2000. Isaiah 37:21-35: Sennacherib's siege of Jerusalem as a challenge to the honour of Yahweh. Old Testament Essays 13(3), 269-282. Minneapolis, MN: Fortress.

Brown, R 1994. The death of the Messiah: From Gethsemane to the grave. A commentary on the passion narratives in the four Gospels. New York: Doubleday.

Brown, R E; Fitzmyer, J A \& Murphy, R E (eds) 1990. The New Jerome Biblical Commentary. New York: Prentice-Hall.

Bujo, B 2003. Vincent Mulago: An enthusiast of African theology, in Bujo, B \& Muya, $\mathrm{J} I$ (eds), African theology in the $21^{\text {st }}$ century, 13-38. Nairobi: Paulines Publications Africa.

Bujo, B \& Muya, J I (eds) 2003. Africa theology in the $21^{\text {st }}$ century: The contribution of the pioneers I. Nairobi: Paulines Publications Africa.

Bultmann, R [1948] 1984. Theologie des Neuen Testaments. Tübingen: Mohr.

Busse, U (ed) 2003, Der Gott Israels im Zeugnis des neuen Testament. FreiburgBasel-Wien: Herder.

Carney, T F 1975. The shape of the past: Models in antiquity. Lawrence: Coronado.

Charlesworth, J H (ed) 1992. The Messiah: Developments in earliest Judaism and Christianity. Minneapolis, MN: Fortress Press.

Clarke, A D \& Winter, B W (eds) 1993. One God, One Lord: Christianity in a word of religious pluralism, $2^{\text {nd }}$ ed. Grand Rapids. Ml: Paternoster Press Carlisle.

Conzelmann, H \& Lindemann, A 1987. Grundriss der Theologie des Neuen Testaments, $4^{\text {th }}$ Ed. Tübingen: Möhr. (Uni-Taschenbücher 1446).

Cothenet, E 1984. Fils de l'homme, in Poupard, P (dir), Dictionnaire des religions I, 697-699. Paris: Preses Universitaires Françaises.

Craffert, P F 1992. More on models and muddles in the social-scientific interpretation of the New Testament: The sociological fallacy reconsidered. Neotestamentica 26(1), 217-239.

Craffert, P F 2001. An exercise in the critical use of models: The "Goodness of fit" of Wilson's sect model, in Pilch, J J (ed), Social scientific models for interpreting the Bible, 21-46. Leiden: Brill.

Dapila, F 2000. Prophetic fulfilment: An examination of "true" and "false" prophecy in the Deuteronomistic works. Old Testament Essays 13, 9-26.

Denaux, A 2000. The monotheistic background of New Testament Christology. Critical reflections on pluralistic theologies of religions, in Merrigan, T \& Haers, J (eds), The Myriad Christ: Plurality and the quest for unity in contemporary Christology, 133-158. Leuven: Leuven University Press.

Denaux, A 2002a. Matthew's story of Jesus' burial and resurrection (Mt 27, 57-28, 20), in Bieringer, $\mathrm{R}$ et al (eds), Resurrection in the New Testament, 123-145. Leuven: Leuven University Press.

Denaux, A 2002b. The parable of the King-Jugde (Lk 19, 12-28) and its relation to the entry story (Lk 19, 29-44). Zeitschrift für die neutestamentlische Wissenshaft und die Kunde der älteren Kirche 93, 35-57.

Denaux, A 2003. Der monotheistische Hintergrund neutestamentlischer Christologie. Kritische Reflexionen über pluralistische Theologien der Religionen, in Busse, U (Hrsg), Der Gott Israels im Zeugnis des neuen Testaments, 193-223. Freiburg: Herder. 
De Villiers P G R 2004. The composition of Revelation 14:1-15:8: Pastiche or perfect pattern? Neotestamentica 38(2), 209-249.

Dietrich, W \& Luz, U (eds) 2002. The Bible in a world context: An experiment in contextual hermeneutics. Grand Rapids, Ml: Eerdmans.

Dillon, R J 1990. Acts of the Apostles, in Brown, R E, Fitzmyer, J A \& Murphy, R E (eds). The New Jerome Biblical Commentary, 722-767. New York: Prentice Hall.

Draper, J A (ed) 2003. Commentary on Romans by Bishop John William Colenso. Pietermaritzburg: Cluster.

Elbert, P 2004. An observation on Luke's composition and narrative style of questions. Catholic Biblical Quarterly 66(1), 98-109.

Elliott, J H 2001. On wooing crocodiles for fun and profit: Confessions of an intact admirer, in Pilch, J J (ed), Social scientific models for interpreting the Bible, 520. Leiden: Brill.

Esler, P F 1994. The first Christians in their social worlds: Social-scientific approaches to New Testament interpretation. London: Routledge.

Fitzmyer, J 1985. The Gospel according to Luke: Introduction, translation and notes. New York: Doubleday.

Focant, C 1999. Du Fils de l'homme asssis (LC 22,69) au fils de l'homme debout (Ac $7,56)$. Enjeux théologique et littéraire d'un changement sémantique, in Verheyden, J (ed), The Unity of Luke-Acts, 562-584. Leuven: Leuven University Press.

Hare, D R A 1983. The Son of Man tradition. Minneapolis, MN: Fortress Press.

Hoffmann, P 1982. Studien zur Theologie der Logienquelle, 3.Aufl. Münster: Aschendorff. (Neutestamentliche Abhandlungen. Neue Folge 8.)

Hoffmann, P 1995. Tradition und Situation. Studien zur Jesusüberlieferung in der Logienquelle und den synoptischen Evangelien. Münster: Aschendorff. (Neutestamentliche Abhandlungen. Neue Folge 28.)

Getui, M N et al (eds) 2001. Interpreting the New Testament in Africa. Nairobi: Acton.

Getui, M N \& Obeng, E A (eds) 2003. Theology of reconstruction: Exploratory essays. Nairobi: Acton.

Gerleman, G 1983. Der Menschensohn. Leiden. Leiden: Brill. (Studia Biblica 1.)

Goldingay, J E \& Wright, C J H (eds) 1993. Yahweh our God Yahweh One: The Old Testament and religious pluralism, in Clarke, A D \& Winter, B W (eds), One God, One Lord: Christianity in a word of religious pluralism, 34-52. Grand Rapids, Ml: Paternoster.

Goulder, M 2002. Psalm 8 and the Son of Man. New Testament Studies 48(1), 1829.

Gourgues, M 1978. À la droite de Dieu: Résurrection de Jésus et actualization du Psaume 110,1 dans le Nouveau Testament. Paris: Lecoffre. (Etudes Bibliques.)

Hahn, F 1963. Christologische Hoheitstitel: Ihre Geschichte in frühen Christentum. Göttingen: Vandenhoeck \& Ruprecht.

Jenkinson, W \& O'Sullivan, $\mathrm{H}$ (eds) 1991. Trends in mission toward the $3^{\text {rd }}$ millennium. Maryknoll, NY: Orbis Books.

Joubert, S 2001. Coming to terms with a neglected aspect of ancient mediterranean reciprocity: Seneca's views on benefit-exchange in De beneficiis as the framework for a model of social exchange, in Pilch, J J (ed), Social scientific models for interpreting the Bible, 48-63. Leiden: Brill. 
Kä Mana 1993. Théologie africaine pour temps de crise. Christianisme et reconstruction de l'Afrique. Paris: Karthala.

Kä Mana 2000. La nouvelle évangelisation en Afrique. Paris: Karthala; Yaoundé: Clé.

Kabasele, M A 2003. La parole se fait chair et sang. Lectures de la Bible dans le contexte africain. Kinshasa: Médiaspaul.

Kalonga, J (dir) 1998. Inculturation de la vie consacrée en Afrique à l'aube du troisième millénaire. Actes du cinquième colloque international. Kinshasa : Carmel Afrique.

Kertelge, K (ed) 1988. Der Prozess gegen Jesus. Historische Rückfrage und theologische Deutung. Freiburg: Herder. (Quaestiones Disputatae 112.)

Koet, B J 1999. Divine communication in Luke-Acts, in Verheyden, J (ed), The unity of Luke-Acts, 731-757. Leuven: Leuven University Press.

Küng, $\mathrm{H}$ et al (eds) 2001. Christianity and world religions: Paths to dialogue with Islam, Hinduism, and Buddhism, Fifth Printing. Maryknoll, NY: Orbis Books.

Kuhn, T S 1970. The structure of scientific revolution. Chicago, IL: University of Chicago Press.

Légasse, S 1974. Jésus devant le Sanhédrin. Recherche sur les traditions évangéliques. Revue Théologique de Louvain 5, 170-179.

Lindemann, A (ed) 2001. The sayings source $Q$ and the historical Jesus. Leuven: Leuven University Press. (Bibliotheca Ephemeridum Theologicarum Lovaniensium 158.)

Loba-Mkole, J-C 1996. Une synthèse d'opinions philologiques sur le Fils de l'homme. Journal of Northwest Semitic Languages 22(1), 107-119.

Loba-Mkole, J-C 2000a. Mark 14:62: Substantial compendium of New Testament Christology. HTS 56(4), 1119-1945.

Loba-Mkole, J-C 2000b. The Kiswahili mwana wa mtu and the Greek ho huios tou anthrôpou, in West, G O \& Dube, M W (eds), The Bible in Africa, 557-566.

Loba-Mkole, J-C 2003. Son of Man and exegetical myths. HTS 59(3), 837-858.

Loba-Mkole, J-C 2004a. Bible translation and inculturation hermeneutics, in Wendland, E R \& Loba-Mkole, J-C (eds), Biblical texts and African languages, 37-58. Leiden: Brill.

Loba-Mkole, J-C 2004b. Scripture video as prophecy and exegesis, in SantediKinkupu, L et Kabasele-Mukenge, A (éds). Une Théologie prophétique pour l'Afrique. Mélanges en l'honneur des Professeurs Dosithée Atal Sa Angang et Réné De Haes. Kinshasa : Facultés Catholiques de Kinshasa, 61-77. (Recherches Africaines de Théologie. Travaux de la Faculté de Théologie 17.)

Loba-Mkole, J-C 2004c. Audience understanding of Jesus' trial (Mk 14:53-15:20). Scriptura. (Forthcoming.)

Loba-Mkole, J-C 2004d. Exégèse contextuelle africaine. Evaluation à partir d'un livre récent. Revue Africaine de Théologie. (Forthcoming).

Lohse, E 1984. Grundriss der neutestamentlichen Theologie, $3^{\text {rd }}$ ed. Stuttgart: Kohlhammer.

Lührmann, D 1969. Die Redaktion der Logienquelle. Anhang zur weiteren Überlieferung der Logienquelle. Neukirchen-Vluyn; Neukirchener. (Wissenschaftliche Monographien zum Alten und Neuen Testament 33.)

Luz, U 1992. The Son of Man in Matthew: Heavenly judge or human Christ. Journal for the Study of the New Testament 48, 3-21.

Malina, B J 1993. The New Testament world: Insights from cultural anthropology. Louisville, KY: Westminster John Knox Press. 
Malina, B J 2001. The Social Gospel of Jesus: The Kingdom in Mediterranean Perspective. Minneapolis, MN: Fortress Press.

Malina, B J \& Pich, J J 2000. Social-science commentary on the book of Revelation. Minneapolis, MN: Fortress Press

Malina, B J \& Rohrbaugh, R L 1992. Social-science commentary on the synoptic Gospels. Minneapolis, MN: Fortress Press.

Manus, U C 2003. Intercultural hermeneutics in Africa: Methods and approaches. Nairobi: Acton.

Marcus, J 2003. Son of Man as Son of Adam. Revue Biblique 110, 38-61; 370-386.

Marshall, I H 1970. Luke: Historian and theologian. Exeter: Paternoster Press.

Matand, J B 1998. L'herméneutique de l'inculturation dans Ac 15 et Ga 2,11-14, in Kalonga, J (dir), Inculturation de la vie consacrée en Afrique à l'aube du troisième millénaire. Actes du cinquième colloque international, 143-168

Matera, F J. 1989. Luke 22, 66-71: Jesus before the "Prebyterion", in Neirynck, F (ed). L'Évangile de Luc, 517-533. Leuven: Leuven University Press.

May, J \& Govender, J 1998. Poverty and inequality in South Africa: Report prepared for the office of the executive deputy president.

Merrigan, T \& Haers, J (eds) 2000. The myriad Christ: Plurality and the quest for unity in contemporary Christology. Leuven: Leuven University Press. (Bibliotheca Ephemeridum Theologicarum Lovaniensium 152.)

Moberly, R B 1992. When was revelation conceived? Biblica 73, 376-393.

Moore, S D 1998. Between Birmingham and Jerusalem: Cultural studies and biblical studies, in Moore, S D (ed), In search of the present: The Bible through cultural studies, 1-32. Atlanta, GA: Scholars Press.

Moore, S D (ed) 1998. In search of the present: The Bible through cultural studies. Atlanta, GA: Society of Biblical Literature. (Semeia 82.)

Mugambi, J N K 2003. Christian theology and social reconstruction. Nairobi: Acton.

Mungua, C [1988] 2000. Son of woman. Nairobi: Spear Books.

Ndayango, C C A 2001. Wunder, Glaube und Leben bei Johannes. Eine exegetischhermeneutische Studie am Beispiel von Joh 3 im Hinblick auf die Inkulturationsaufgabe. Bonn: Borengässer. (Arbeiten zur Interkulturalität 3.)

Ndayango, C C A 2003. La contribution de l'exégèse biblique à la tâche de l'inculturation. Revue Africaine de Théologie 53, 45-62.

Ndung'u, N 2003. Towards the recovery of African identity, in Getui, M N \& Obeng, E A (eds). Theology of reconstruction, 258-265. Nairobi: Action.

Neirynck (ed) 1989. L'Évangile de Luc. The Gospel of Luke: Revised and enlarged edition of L'Évangile de Luc. Problèmes littéraires et théologiques. Leuven: Leuven University Press. (Bibliotheca Ephemeridum Theologicarum Lovaniensium 32.)

Ntakarutimana, E 2003. Alphonse Ngindu Mushete: The problem of religious knowledge, in B Bujo, B \& Muya, J I (eds), Africa theology in the $21^{\text {st }}$ Century, 64-72.

Noël, F 1994: De compositie van het Lucasevangeilie in zijn relatie tot Marcus. Het probleem van de "grote weglating. Brussel. (AWL'K 150.)

Nürnberger, K 1999. Prosperity, poverty and pollution: Managing the approaching crisis. Pietermaritzburg: Cluster.

Odoemene, N 2003. Jesus of Nazareth the divine anthropology and African Christian's self-awareness. Journal of inculturation theology 5(1), 23-40.

Okure, T 2003. Invitation to African women's hermeneutical concerns, in Getui, M N et al (eds), Interpreting the New Testament in Africa, 42-67. Nairobi: Action. 
Penoukou, E J 1991. The churches of Africa: Their identity? Their mission?, in Jenkinson, W \& O'Sullivan, $\mathrm{H}$ (eds), Trends in mission toward the $3^{\text {rd }}$ millennium, 39-45. Maryknoll, NY: Orbis Books.

Pieterse, H J C 2001. Preaching in a context of poverty. Pretoria: Unisa Press.

Pilch, J J (ed) 2001. Social scientific models for interpreting the Bible: Essays by the context group in honor of Bruce J Malina. Leiden: Brill. (Biblical Interpretation Series.)

Poupard, P (dir) 1984. Dictionnaire des religions I. Paris: Presses Universitaires Frainçaises.

Prinsloo, G T M 2000. Sennacherib, Lachish and Jerusalem: Honour and shame. Old Testament Essays 13(3), 348-363.

Quarshie, B Y 2000. The significance of biblical studies for African Christian theology. Journal of African Christian Though 3(1), 17-26.

Radl, W 1988. Sonderüberlieferungen bei Lukas? Traditionsgeschichtliche Fragen zu Luke 22,67f; 23,6-12, in Kertelge, K (ed). Der Prozess gegen Jesus, 131-147. Freiburg: Herder.

Rojas-Flores, G 2004. The book of Revelation and the first years of Nero's reign. Biblica 85(3), 375-392.

Rowland, C 1999 (ed.), The Cambridge companion to liberation theology. Cambridge: Cambridge University Press.

Sanders, E P 1993. The historical figure of Jesus. New York: Allen Lane Penguin.

Schneider, G 1988. Das Verfahren gegen Jesus in der Sicht des dritten Evangeliums (Lk 22, 54-23, 25), in Kertelge, K (ed), Der Prozess gegen Jesus, 111-130.

Segovia, F F 1995. "And they began to speak in other yongues": Competing modes of discourse in contemporary biblical criticism, in Segovia, F F \& Tolbert, M A (eds), Reading from this place 1, 1-32.

Segovia, F F \& Tolbert, M A (eds) 1995. Reading from this place 1: Social location and biblical interpretation in the United States. Minneapolis, MN: Fortress Press. Minneapolis, MN: Frotress.

Slater, T B 2003. Dating the apocalypse to John. Biblica 84, 252-258.

Soards, M L 1987. The passion according to Luke: The special material of Luke 22. Sheffield: Sheffield Academic Press. (Journal for the Study of the New Testament SS 14.)

Stiebert, J \& Walsch, J T 2001. Does the Hebrew Bible have anything to say about homosexuality? Old Testament Essays 14(1), 119-152.

Tamez, E 2002a. Reading the Bible under a sky without stars, in Dietrich, W \& Luz, U (eds), The Bible in a world context, 3-15. Grand Rapids, MI: Eerdmans.

Tamez, E 2002b. A star illuminates the darkness, in Dietrich, W \& Luz, U (eds), The Bible in a world context, 53-58. Grand Rapids, MI: Eerdmans.

Taylor, N H 1999a. Prolegomena to reconstructing the eschatological teaching of Jesus. Neotestamentica 33(1), 145-160.

Taylor, N H 1999b. Jerusalem and the temple in early Christian life and teaching. Neotestamentica 33(2), 445-461.

Taylor, N H 2003. Stephen, the temple, and early Christian eschatology. Revue Biblique 110(1), 62-87.

Theuri, M 2003. Poverty in Africa, in Getui, M N \& Obeng, E A (eds), Theology of reconstruction, 230-242. Nairobi: Action.

Thiamalenga, N 1977. Exégèse biblique et philosophie du langage. Revue Africaine de Théologie 1, 165-184. 
Tuckett, C M 2001. The Son of Man and Daniel 7: Q and Jesus, in Lindemann, A (ed), The sayings source $Q$ and the historical Jesus, 371-394.

Ukpong, J S 2000. Developments in Biblical interpretation in Africa: Historical and hermeneutical directions, in West, G O \& Dube, M W, Bible in Africa, 11-28. Leiden: Brill.

Ukpong, J S 2001a. Bible reading with a community of ordinary readers, in $\mathrm{M} \mathrm{N}$ Getui, M N et al (eds), Interpreting the New Testament in Africa, 188-222. Leiden: Brill.

Ukpong, J S [2001]b. Essays in inculturation hermeneutics: Guidelines for the publication of essays on inculturation hermeneutics. Unpublished style-sheet.

Ukpong, J S 2002a. Inculturation hermeneutics: An African approach to biblical interpretation, in Dietrich, W \& Luz, U (eds), The Bible in a world context, 1732. Grand Rapids,MI: Eerdmans.

Ukpong, J S 2002b. The story of Jesus' birth (Luke 1-2): An African reading, in Dietrich, W \& Luz, U (eds), The Bible in a world context, 59-70. Grand Rapids, MI: Eerdmans.

Ukpong, J S 2003. Biblical interpetation in Africa: Transcending the boundaries of inculturation and liberation. Journal of Inculturation Theology 5(2), 105-122.

United Nations Development Programme (UNDP) 1997. Human Development Report 1997. New York: Oxford University Press.

Vaage, L E 1991. The Son of Man sayings in Q: Stratigraphical location and significance. Semeia 55, 103-129.

Van Aarde, A 1994. The epistemic status of the New Testament and the emancipatory living of the historical Jesus in engaged hermeneutics. Neotestamentica 28(2), 575-596.

Van Aarde, A 2001. Fatherless in Galilee: Jesus as child of God. Harrisburg, PA: Trinity Press International.

Verheyden, J (ed) 1999. The Unity of Luke-Acts. Leuven: Leuven University Press. (Bibliotheca Ephemeridum Theologicarum Lovaniensium 142.)

Vermes, G 1967. The use of bar nash/bar nasha in Jewish Aramaic, in Black, M (ed), An Aramaic approach to the Gospels and Acts, 310-328. Oxford: Oxford University Press.

Villa-Vicencio, C 1992. A theology of reconstruction: Nation building and human rights. Cambridge: Cambridge University Press.

Villa-Vicencio, C 1999. Liberation and reconstruction, in Rowland, C (ed), The Cambridge companion to liberation theology, 153-176. Cambridge: Cambridge University Press.

Vielhauer, P 1965. Aufsätze zum Neuen Testament. München: Kaiser. (Theologische Bucherei. Neues Testament 31.)

Vögtle, A 1994. Die "Gretchenfrage" des Menschensohnproblems. Bilanz und Perspeckive. Freiburg-Basel-Wien: Herder. (Quaestiones Disputatae 152.)

Wendland, E R \& Loba-Mkole, J-C (eds) 2004. Biblical Texts and African Languages. Nairobi: Acton.

West, G O 1993. Contextual Bible study. Pietermaritzburg: Cluster.

West, G O 1995. Biblical hermeneutics of liberation: Modes of reading the Bible in the South African context, $2^{\text {nd }}$ ed. Pietermaritzburg: Cluster: Orbis Books.

West, G O \& Dube, M W 1996. An introduction: How we have come to "read with", in Bird, A et al (eds), "Reading with", 7-17.

West, G O 1999. The academy of the poor: Towards a dialogical reading of the Bible. Sheffield: Sheffield Academic Press. 
West, G O 2000a. Mapping African and Biblical interpretation, in West, G O \& Dube, M W (eds), Bible in Africa, 29-53. Atlante, GA: Scholars Press. (Semeia 73.)

West, G O 2000b. Contextual Bible study in South Africa: A resource for reclaiming and regaining land, dignity and identity, in West, G O \& Dube, M W (eds), The Bible in Africa: Transactions, trajectories and trends, 595-610. Leiden: Brill.

West, G O \& Dube, M W (eds) 2000. The Bible in Africa: Transactions, trajectories and trends. Leiden: Brill.

Wilson, J C 1993. The problem of the domitianic date of Revelation. New Testament Studies 39, 587-605.

Wink, W 2002. The human being: Jesus and the enigma of the Son of the man. Minneapolis, MN: Fortress Press.

Yeboah-Keyeame, S 2000. Introduction to miracle deliverance church. Journal of African Christian Thought 3(2), 52-53. 